\title{
Habitat-based models of cetacean density and distribution in the central North Pacific
}

\author{
Karin A. Forney ${ }^{1, *}$, Elizabeth A. Becker ${ }^{1,2}$, Dave G. Foley ${ }^{\ddagger}$, Jay Barlow ${ }^{3}$, \\ Erin M. Oleson ${ }^{4}$ \\ ${ }^{1}$ Marine Mammal and Turtle Division, Southwest Fisheries Science Center, National Marine Fisheries Service, \\ National Oceanic and Atmospheric Administration, 110 Shaffer Rd, Santa Cruz, California 95060, USA \\ ${ }^{2}$ ManTech International Corporation, 420 Stevens Ave, Solana Beach, California 92075, USA \\ ${ }^{3}$ Marine Mammal and Turtle Division, Southwest Fisheries Science Center, National Marine Fisheries Service, \\ National Oceanic and Atmospheric Administration, 8901 La Jolla Shores Dr, La Jolla, California 92037, USA \\ ${ }^{4}$ Protected Resources Division, Pacific Islands Fisheries Science Center, National Marine Fisheries Service, \\ National Oceanic and Atmospheric Administration, 1601 Kapiolani Blvd, Honolulu, Hawaii 96814, USA
}

\begin{abstract}
The central North Pacific Ocean includes diverse temperate and tropical pelagic habitats. Studies of the abundance and distribution of cetaceans within these dynamic marine ecosystems have generally been patchy or conducted at coarse spatial and temporal scales, limiting their utility for pelagic conservation planning. Habitat-based density models provide a tool for identifying pelagic areas of importance to cetaceans, because model predictions are spatially explicit. In this study, we present habitat-based models of cetacean density that were developed and validated for the central North Pacific. Spatial predictions of cetacean densities and measures of uncertainty were derived based on data collected during 15 large-scale shipboard cetacean and ecosystem assessment surveys conducted from 1997 to 2012. We developed generalized additive models using static and remotely sensed dynamic habitat variables, including distance to land, sea-surface temperature (SST), standard deviation of SST, surface chlorophyll concentration, seasurface height (SSH), and SSH root-mean-square variation. The resulting models, developed using new grid-based prediction methods, provide finer scale information on the distribution and density of cetaceans than previously available. Habitat-based abundance estimates around Hawaii are similar to those derived from standard line-transect analyses of the same data and provide enhanced spatial resolution to inform management and conservation of pelagic cetacean species.
\end{abstract}

KEY WORDS: Central North Pacific - Cetacean abundance - Generalized additive model · Habitat-based density model $\cdot$ Pelagic conservation $\cdot$ Remote sensing

\section{INTRODUCTION}

Spatially explicit estimates of species density are needed to better assess potential impacts of all marine activities that may adversely affect cetaceans, including seismic surveys, marine renewable energy development, oil and gas exploration, and naval activities. For example, to ensure compliance with United States (US) regulations under the Endan- gered Species Act and the Marine Mammal Protection Act, the US Navy must estimate the number of marine mammals that might be affected by their atsea training and testing activities. Such quantitative assessments require estimates of species density (animals $\mathrm{km}^{-2}$ ) in specific areas where activities will occur. Line-transect density estimates for most cetacean species have been derived for waters within the US Exclusive Economic Zone around Hawaii (HI 
EEZ) (Barlow 2006, Barlow \& Rankin 2007, Bradford et al. 2013); however, these studies provide only uniform density estimates within that broad region with little or no information on spatial patterns. Recent advances in modeling cetacean densities based on habitat variables have provided new tools for assessing and minimizing impacts of human activities on marine mammals (Ferguson et al. 2006, Barlow et al. 2009, Becker et al. 2012a,b,c, Forney et al. 2012, Goetz et al. 2012, Keller et al. 2012, Redfern et al. 2013). These habitat-based density models yield finer scale information than traditional line-transect analyses, particularly in the well-surveyed California Current Ecosystem (CCE) and eastern tropical Pacific (ETP). However, the US Navy and other users of the marine environment also require density estimates for cetaceans in other regions where survey coverage may be limited and cetacean sighting rates are low. In particular, waters of the central North Pacific Ocean have been poorly studied but include large geographic regions with a potential for naval activity (US Department of the Navy 2008).

Becker et al. (2012b) developed preliminary habitat-based density models for cetaceans within waters of the central North Pacific based on coarse survey coverage in that area during 1997, 2002, and 2005, and additional survey effort within portions of the eastern tropical Pacific from 1998 to 2006. Predictor variables included distance to land and a variety of dynamic oceanographic variables derived from remotely sensed measures. Model-based density estimates developed for 10 species/species groups were comparable to standard line-transect estimates derived within the HI EEZ from the same survey data (Barlow 2006, Barlow \& Rankin 2007, Becker et al. 2012 b) but provided greater spatial resolution, especially near the Hawaiian Islands. However, no independent survey data were available to validate model performance, which is an important aspect of developing marine species density models for management (Barlow et al. 2009, Becker et al. 2010, Forney et al. 2012). The objective of the present study was to validate the original models developed in Becker et al. (2012b) using new survey data collected in 2010 within the HI EEZ and in 2011 and 2012 in waters surrounding Palmyra Atoll/Kingman Reef. Based on the validation results, our second objective was to update the habitat-based models of cetacean densities using the combined 1997-2012 survey data set and examine whether the addition of new survey data improved the models. New modeling methods that allowed model predictions to be applied directly on a $25 \times 25 \mathrm{~km}$ spatial grid at monthly time scales were implemented, providing spatial estimates of cetacean density and jackknife estimates of model uncertainty for the entire Central Pacific study area.

\section{METHODS}

\section{Field methods}

The data used for modeling and model validation were derived from 15 systematic line-transect cetacean and ecosystem ship surveys conducted by the National Oceanic and Atmospheric Administration (NOAA) Southwest Fisheries Science Center and the Pacific Islands Fisheries Science Center between 1997 and 2012. Surveys were completed along predetermined transect lines within the temperate eastern Pacific, around Hawaii and other central Pacific islands, and in the ETP (Table 1), aboard 52 to $68 \mathrm{~m}$ research vessels, including the NOAA ships 'David Starr Jordan', 'McArthur', 'McArthur II', and 'Oscar

Table 1. Periods of marine mammal and ecosystem surveys conducted within the central Pacific study area during 1997-2012. ETP: eastern tropical Pacific

\begin{tabular}{|c|c|c|c|}
\hline $\begin{array}{l}\text { Cruise } \\
\text { number }\end{array}$ & Period & $\begin{array}{c}\text { Research } \\
\text { vessel }\end{array}$ & $\begin{array}{l}\text { Survey } \\
\text { region }\end{array}$ \\
\hline 1607 & Mar-Jun 1997 & McArthur & $\begin{array}{l}\text { Temperate } \\
\text { North Pacific }\end{array}$ \\
\hline 1610 & Oct-Dec 1998 & McArthur & ETP \\
\hline 1611 & Aug-Sep 1998 & Endeavor & ETP \\
\hline 1614 & Aug-Sep 1999 & McArthur & ETP \\
\hline 1616 & Jul-Sep 2000 & McArthur & ETP \\
\hline 1621 & Jul-Dec 2002 & $\begin{array}{l}\text { David Starr } \\
\text { Jordan }\end{array}$ & $\begin{array}{c}\text { Hawaiian } \\
\text { Archipelago }\end{array}$ \\
\hline 1622 & Oct-Dec 2002 & McArthur & $\begin{array}{c}\text { Hawaiian } \\
\text { Archipelago }\end{array}$ \\
\hline 1623 & Aug-Sep 2003 & McArthur II & ETP \\
\hline 1624 & Aug, Nov 2003 & $\begin{array}{l}\text { David Starr } \\
\text { Jordan }\end{array}$ & ETP \\
\hline 1629 & Jul-Nov 2005 & McArthur II & $\begin{array}{c}\text { Central } \\
\text { Pacific Islands }\end{array}$ \\
\hline 1631 & Aug-Sep 2006 & McArthur II & ETP \\
\hline 1641 & Aug-Dec 2010 & McArthur II & $\begin{array}{c}\text { Hawaiian } \\
\text { Archipelago }\end{array}$ \\
\hline 1642 & Sep-Oct 2010 & $\begin{array}{c}\text { Oscar Elton } \\
\text { Sette }\end{array}$ & $\begin{array}{c}\text { Hawaiian } \\
\text { Archipelago }\end{array}$ \\
\hline 1108 & Oct-Nov 2011 & $\begin{array}{l}\text { Oscar Elton } \\
\text { Sette }\end{array}$ & $\begin{array}{c}\text { Palmyra } \\
\text { Atoll }\end{array}$ \\
\hline 1203 & Apr-May 2012 & $\begin{array}{l}\text { Oscar Elton } \\
\text { Sette }\end{array}$ & $\begin{array}{l}\text { Palmyra } \\
\text { Atoll }\end{array}$ \\
\hline
\end{tabular}


Elton Sette', and the R/V 'Endeavor' (Hamilton et al. 2009, Bradford et al. 2014). Our central North Pacific study area encompassed $24099210 \mathrm{~km}^{2}$, with survey effort concentrated in waters of the HI EEZ (Fig. 1).

Standardized visual line-transect protocols were followed during all surveys by a team of 3 observers stationed on the flying bridge of the vessel (Kinzey et al. 2000). The team included starboard and port observers searching for animals using pedestalmounted $25 \times 150$ binoculars, and a third observer/ data recorder who searched from a central position using the unaided eye and $7 \times 50$ handheld binoculars. Six observers rotated among these 3 positions every $40 \mathrm{~min}$, providing a $2 \mathrm{~h}$ rest period between shifts. When cetaceans were detected within $5.5 \mathrm{~km}$ of the trackline, the ship typically diverted from the transect line ('closing mode') and observers were considered 'off-effort' for group size estimation and species identification. Each observer recorded separate and confidential estimates of best, high, and low group size along with estimated percentages of each species present in the group. Occasionally, operational constraints required the ship to continue along the trackline in 'passing mode' while the observers remained 'on-effort' without approaching the sighted animals. Species were identified to the finest possible taxonomic level. In addition to sighting information (time, position, species present, and estimates of

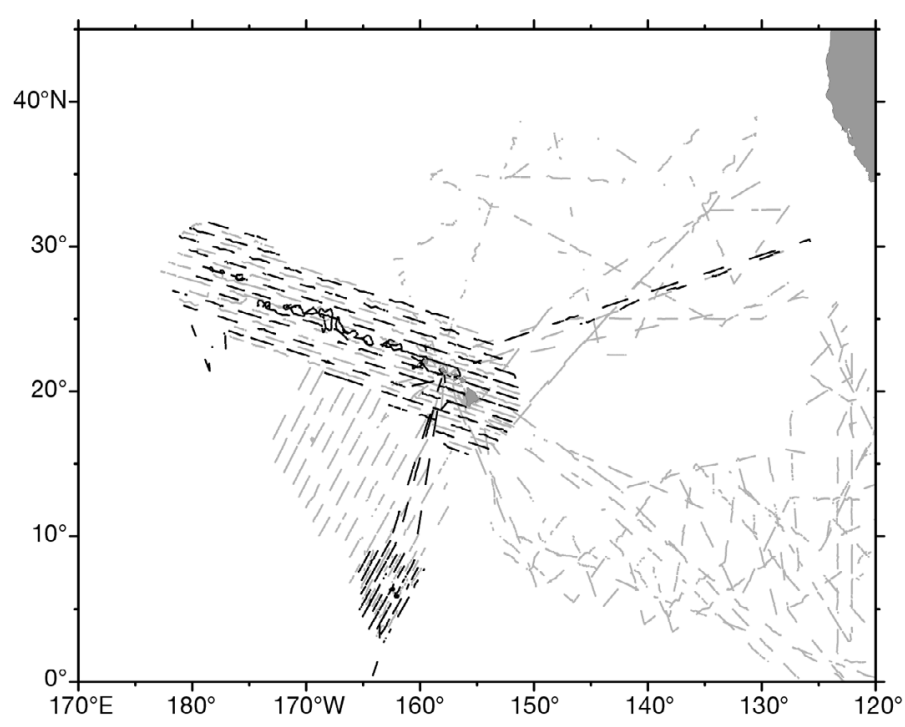

Fig. 1. Transect coverage for surveys conducted between 1997 and 2012 in the temperate eastern Pacific, around Hawaii and other Pacific Islands, and in the eastern tropical Pacific that included effort within our central North Pacific study area. Transects included in the previous Becker et al. (2012b) models are shown in gray; new surveys included in this study are shown in black group size and species composition), effort data such as Beaufort sea state, wind speed, swell height, and visibility were recorded on a laptop computer connected to the ship's navigation system.

Nine species, for which Becker et al. (2012b) developed original models, were included in this study: pantropical spotted dolphin Stenella attenuata, spinner dolphin Stenella longirostris, striped dolphin Stenella coeruleoalba, rough-toothed dolphin Steno bredanensis, common bottlenose dolphin Tursiops truncatus, false killer whale Pseudorca crassidens, short-finned pilot whale Globicephala macrorhynchus, sperm whale Physeter macrocephalus, and Bryde's whale Balaenoptera edeni. Becker et al. (2012b) also developed a model for a combined group of 'other dolphins' which included shortbeaked common dolphin Delphinus delphis and Pacific white-sided dolphin Lagenorhynchus obliquidens; however, the 2010 validation survey did not include any sightings of these species so they were not considered in the present study.

\section{Analytical methods}

We updated the original habitat-based models of cetacean densities using a 2-step process in which (1) we validated the original models using the new survey data collected in 2010, and (2) based on the validation results, we developed new models using the combined 1997-2012 data set and improved modeling methods.

\section{Data processing and predictor variables}

Samples for modeling were created by dividing the continuous survey effort into segments of approximately $10 \mathrm{~km}$ length, as described by Becker et al. (2010). Only segments with average sea states of 0-6 on the Beaufort scale were used to develop models, corresponding to the conditions included in previous studies of cetacean density within this study area (Barlow 2006, Barlow \& Rankin 2007, Becker et al. 2012b, Bradford et al. 2013). Species-specific sighting data were summarized for each segment as the total number of groups encountered and the average group size (calculated as the average of the best group size estimates for all observers). In rare cases where there was no best estimate, the low estimate of group size was used (Kinzey et al. 2000). Sighting data were truncated at a $5.5 \mathrm{~km}$ perpendicular distance to eliminate the most distant groups (Buckland 
et al. 2001) and to maintain consistency with the estimates of the species-specific effective strip width previously derived from these survey data (Barlow et al. 2011). A different, acoustic-and-visual protocol was used during the 2010-2012 surveys to obtain total group size estimates for sightings of false killer whales, because this species can be found in widely scattered, associated subgroups spanning 10s of kilometers (Baird et al. 2008a). To maintain consistency with previous surveys on which the acoustically detected and more distant subgroups would not have been recorded by visual observers, we included only those subgroups within the $5.5 \mathrm{~km}$ truncation distance and adjusted the total group size based on the estimated visual detection probability of each subgroup, following the methods of Bradford et al. (2014).

The ultimate goal of a habitat-based density model is to predict species density based on dynamic environmental variables, so longitude and latitude are often purposefully excluded as predictor variables (Barlow et al. 2009, Becker et al. 2010, 2012a, Forney et al. 2012). However, latitude and longitude were included in the original models for the central North Pacific because of the limited number of sightings and coarse transect coverage available for model development (Becker et al. $2012 b)$. In the present study, given the additional 2010-2012 survey data, we developed models both with and without latitude and longitude. Distance to land $(\mathrm{km})$ was included in the new models as a potential predictor variable and was calculated as the great circle distance between each segment midpoint and coastline points from the Global SelfConsistent Hierarchical High-Resolution Shorelines database, Version 2.2.2 (Wessel \& Smith 1998) (www. ngdc.noaa.gov/mgg/shorelines/gshhs.html).

Dynamic habitat predictor variables were derived for the midpoint of each segment from monthly mean values of the following remotely sensed measures: sea-surface temperature $\left(\mathrm{SST}_{;}{ }^{\circ} \mathrm{C}\right)$ and its standard deviation (SSTsd), the natural logarithm of the seasurface chlorophyll concentration (lnCHL; $\mathrm{mg} \mathrm{m}^{-3}$ ), sea-surface height $\left(\mathrm{SSH}_{;} \mathrm{m}\right)$, and sea-surface height root-mean-square variation (SSHrms; $\mathrm{m})$. Satellitebased SST data derived using optimal interpolation methods (Reynolds \& Smith 1994) were used in the models as they provide a daily, gap-free SST product at $25 \mathrm{~km}$ spatial resolution (Reynolds et al. 2007). These 'blended' SST data combine in situ and infrared satellite sensor measurements to virtually eliminate data gaps produced by cloud cover, and have been used successfully in habitat-based density models for cetaceans (Becker et al. 2012a). SSTsd was used as a proxy for frontal regions, since oceanic processes such as fronts and eddies often result in surface SST gradients. Sea-surface chlorophyll concentration values (Moderate Resolution Imaging Spectroradiometer [MODIS] carried aboard NASA's Aqua spacecraft) were obtained at a spatial resolution of 0.2 degrees (i.e. a $5 \times 5$ pixel box with a single pixel resolution of $9 \mathrm{~km}$ or approximately $81 \mathrm{~km}^{2}$ ). MODIS chlorophyll data are not available for the time period prior to 2002, so for the 1998-2001 survey data, we used chlorophyll concentration values based on the Sea-viewing wide Field-of-View Sensor (SeaWiFS) carried aboard the Orbview-2 spacecraft (Geoeye; not available post-2010), calibrated to the MODIS values used for 2002-2012 via regression. Chlorophyll data for 1997 were not available from either sensor. SSH (Centre Nationale pour les Etudes Spatiale /Aviso) was calculated within a $0.5 \times 0.5$ degree box. SSTsd and SSHrms were calculated within a $1 \times 1$ degree box centered on the segment midpoint; the latter is a common oceanographic measure of mesoscale variability.

\section{Previous model validation}

The original habitat-based models developed from the 1997-2006 central North Pacific survey data (Becker et al. 2012b) were used to predict cetacean density and distribution patterns for AugustDecember 2010, when a systematic ship survey similar to the one conducted in 2002 was conducted within waters of the HI EEZ. Consistent with the approach used in the original study, density estimates for each segment were smoothed using inverse distance weighting (Becker et al. 2012b), and the resulting predictions of distribution and density were visually compared with actual sightings made during the 2010 survey. For comparison, density estimates were also made based on environmental conditions in 2002, the year the first systematic survey of the HI EEZ was conducted. This approach provided us with 2 sets of plots for evaluating the original models' predictive ability, one showing predictions for a period when survey data were included in model development (2002) and the second showing predictions on a novel data set (2010). In addition to the visual comparison of predicted densities and actual sightings, ratios of the 2002 and 2010 observed-to-predicted abundance were derived to provide a quantitative evaluation of the models' predictive power on an independent data set. 


\section{New model development}

There are many analytical approaches for developing spatial models of species distribution (Syphard \& Franklin 2009, Beale et al. 2010, Booth et al. 2013), and the choice of a suitable method depends on the nature of the data and the study objectives. Generalized additive models (GAMs; Hastie \& Tibshirani 1990) have been extensively validated and shown to perform well for the type of cetacean survey data in our study (Ferguson et al. 2006, Barlow et al. 2009, Forney et al. 2012, Becker et al. 2012a). The objective of the present study was to evaluate whether the addition of new data within this sparsely surveyed region would improve the previously developed models; therefore, we retained the basic framework of those previously developed GAMs in this analysis (Becker et al. 2012b).

GAMs incorporating the additional 2010-2012 survey data were developed separately for each of the 9 species to create updated habitat-based density models within the central North Pacific. Previous studies (Ferguson et al. 2006, Barlow et al. 2009, Becker et al. 2010, 2012a,c, Forney et al. 2012) modeled group encounter rate (groups per linear distance searched) and group size separately and combined these 2 modeled parameters with an estimate of the average group detection probability to estimate overall animal density within a line-transect framework (Buckland et al. 2001). However, this approach did not explicitly adjust for within-survey variation in the effective area searched as observation conditions (e.g. sea state) changed. In this study, we have applied more recent methods developed by Becker et al. (2012b) to model the expected number of animal groups per effective area searched based on actual observation conditions (hereafter 'group density') to improve model accuracy. Modeled group densities were then combined with model-based estimates of group size to estimate overall animal density within a line-transect framework (Becker et al. 2012b).

Group density (groups $\mathrm{km}^{-2}$ ) was modeled as a quasi-Poisson process, with the number of groups detected on each segment as the response variable, the habitat variables derived at each segment midpoint as predictor variables, and the natural log of the effective area searched on that segment as an offset. The effective area searched was estimated as the segment length $\times$ twice the effective half-strip width (ESW). Species-specific values of ESW for each segment were estimated based on the recorded viewing conditions on that segment (sea state, swell anomaly) using the coefficients estimated by Barlow et al.
(2011) for all surveys through 2012. For species with a sample size of at least 50 sightings, group size models were developed using all segments with sightings, with the natural log of group size as the response variable and an identity link function (Ferguson et al. 2006). The average group size (null model) was used for species with a smaller sample size.

Separate group density and group size GAMs were built using the step.gam function in the statistical software package TIBCO Spotfire $\mathrm{S}+{ }^{\circledR} 8.1$ for Windows. We used a step-wise forward/backward selection procedure (Ferguson et al. 2006) based on Akaike's information criterion (AIC; Akaike 1973) for selecting the variables included in each model and the degrees of freedom for the smoothing splines (Becker et al. 2012b). For all models, a maximum of 3 degrees of freedom was allowed in the smoothing splines to capture nonlinear relationships without adding unrealistic complexity to the functions (Forney 2000, Ferguson et al. 2006). A correlation analysis revealed no strong correlations (i.e. all less than \pm 0.51 ) between any of the predictor variables, with the exception of longitude and distance to land (0.75). Based on preliminary analyses, we ultimately included both of these variables as potential predictors in the models, because distance to land was effective at capturing the nearshore distribution of island-associated populations (e.g. bottlenose dolphin) and latitude and longitude were included to provide broad geographic distribution patterns.

Spatial autocorrelation is often present in species distribution data, and must be accounted for when statistically evaluating species-habitat associations (Dormann 2007). For predictive, habitat-based models of species density, where the objective is not hypothesis testing but rather the characterization of observed distribution patterns, spatial autocorrelation is implicitly included in the model. For this reason, modeled relationships cannot be applied to other study areas where spatial autocorrelation patterns may differ. In this study, we evaluated speciesspecific spatial autocorrelation via Moran's I correlograms, with spatial lags from 0 to $100 \mathrm{~km}$ in $10 \mathrm{~km}$ increments and weights equal to the inverse of the great circle distance between segment mid-points. We evaluated significance by randomly permuting the sighting data 500 times and re-calculating Moran's I for each of the 10 lags. Autocorrelation was considered significant if the observed Moran's I value was outside of the $95 \%$ confidence interval of the simulated Moran's I values.

Species-specific density (number of animals $\mathrm{km}^{-2}$ ) was estimated by incorporating the group density 
and group size models into the standard line-transect equation (Buckland et al. 2001):

$$
D_{i}=\left(\frac{n_{i}}{A_{i}}\right) \times S_{i} \times \frac{1}{g(0)}
$$

where $i$ is the segment, $n_{i} / A$ is the predicted group density for segment $i$ (number of sightings, $n_{i}$, per effective area searched, $\left.A_{i}\right), s_{i}$ is the predicted group size for segment $i$, and $g(0)$ is the probability of detecting a group of animals on the trackline. Following the methods of Becker et al. (2012b), estimates of $g(0)$ were derived from previously published studies (see Barlow 2003, 2006) and weighted based on the number of small and large groups recorded in the 1997-2012 survey data. Weighted $g(0)$ values used in this study were 0.988 (pantropical spotted dolphin), 0.972 (spinner dolphin), 0.952 (striped dolphin), 0.897 (rough-toothed dolphin), 0.900 (common bottlenose dolphin), 0.824 (false killer whale), 0.896 (shortfinned pilot whale), 0.870 (sperm whale), and 0.900 (Bryde's whale).

Chlorophyll data were not available for 1997, so in addition to the models built using the full suite of potential predictor variables, a second set of group density and group size models was developed for each species that excluded chlorophyll. We thus built one set of models using the 1997-2012 survey data that excluded chlorophyll and a second set with survey data from 1998-2012 that included the full suite of predictor data. As noted previously, we also built separate models with and without latitude and longitude. This process provided us with 4 sets of models for each species.

\section{Model evaluation and selection}

Within each of the 4 sets of models, the best GAM was selected based on minimizing AIC, resulting in 4 candidate models for each of the 9 species. To evaluate model performance, we compared explained deviance, average squared prediction error (ASPE; Hastie \& Tibshirani 1990), and ratios of observed to predicted abundance, calculated for each segment and summed across all segments to obtain study area density ratios (Redfern et al. 2008, Barlow et al. 2009, Becker et al. 2010, 2012a, Forney et al. 2012). For all species, the 4 candidate models exhibited similar performance (Table 2), and there was no single 'best' model. Therefore, we implemented a discrete modelaveraging approach (Burnham \& Anderson 1998, Wintle et al. 2003, Claeskens \& Hjort 2008), weighting the density predictions from each of the 4 similar models equally to produce final density model-averaged predictions.

Density predictions were plotted and visually compared to actual sightings made during the 1997-2012 surveys. Unlike previous efforts, where segmentspecific predictions from the models were interpolated to provide values for the entire study area (Barlow et al. 2009, Becker et al. 2010, Forney et al. 2012, Becker et al. 2012a,b), we used the models to predict density in each cell of a $25 \times 25 \mathrm{~km}$ grid of the study area. Separate grid predictions were made based on the monthly environmental conditions and averaged across the 26 mo of the study period (or 21 mo for the models that included lnCHL, because this variable was not available during 1997). Grid cell densities for all 4 models were then averaged to calculate mean predicted species density. In addition, observed and predicted densities were calculated separately for 2002 and 2010 to obtain ratios specific to the HI EEZ, where survey effort was concentrated during those 2 years.

Model uncertainty was estimated using a jackknife procedure (Efron \& Tibshirani 1993) in which the survey days were randomly divided into 10 sets, and 1 set (comprising $10 \%$ of the survey days) was withheld for each of 10 jackknife iterations. All 4 model types were re-estimated for each jackknife data set using the step-wise forward/backward selection procedure and model-averaging as described in 'New model development'.

\section{Abundance comparisons}

To examine potential bias in the resulting models, we compared abundance estimates derived within the HI EEZ based on model predictions with available uniform standard line-transect abundance estimates derived from the 2002 and 2010 HI EEZ surveys (Barlow 2006, Barlow \& Rankin 2007, Bradford et al. 2013). For this comparison, the model-based abundance of each species was calculated for each grid cell as the product of the predicted animal density in that cell $x$ the cell area (in $\mathrm{km}^{2}$ ), subtracting any portion of the grid cell outside the HI EEZ or on the islands. These individual grid cell abundances were then summed to obtain an overall model-based abundance estimate for the entire HI EEZ. Area calculations were completed using the R packages geosphere and gpclib in R (Version 3.0.3, R Core Team 2014). Lognormal confidence intervals for the model-based abundance estimates within the HI EEZ were derived from the jackknife standard errors using standard formulae. 


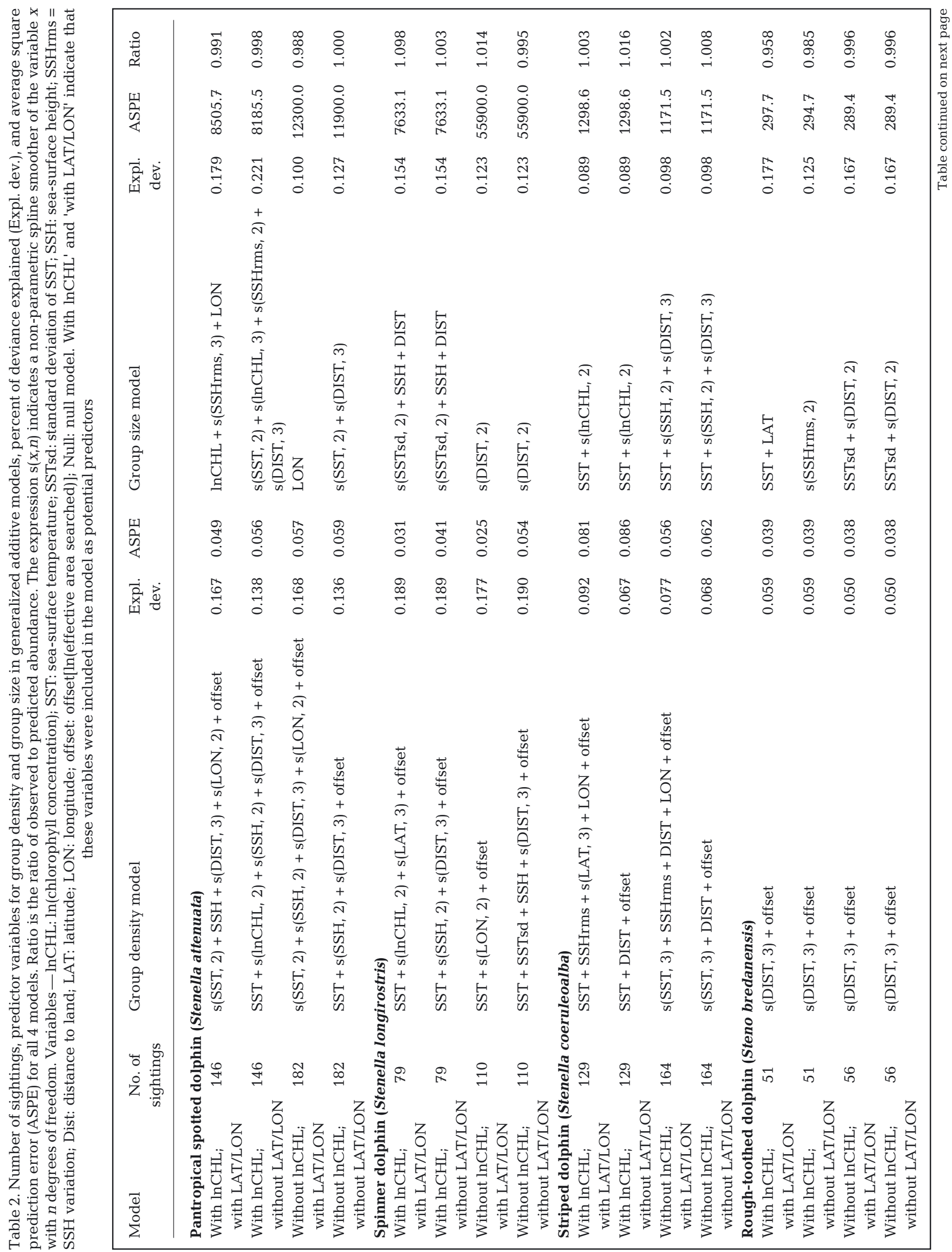




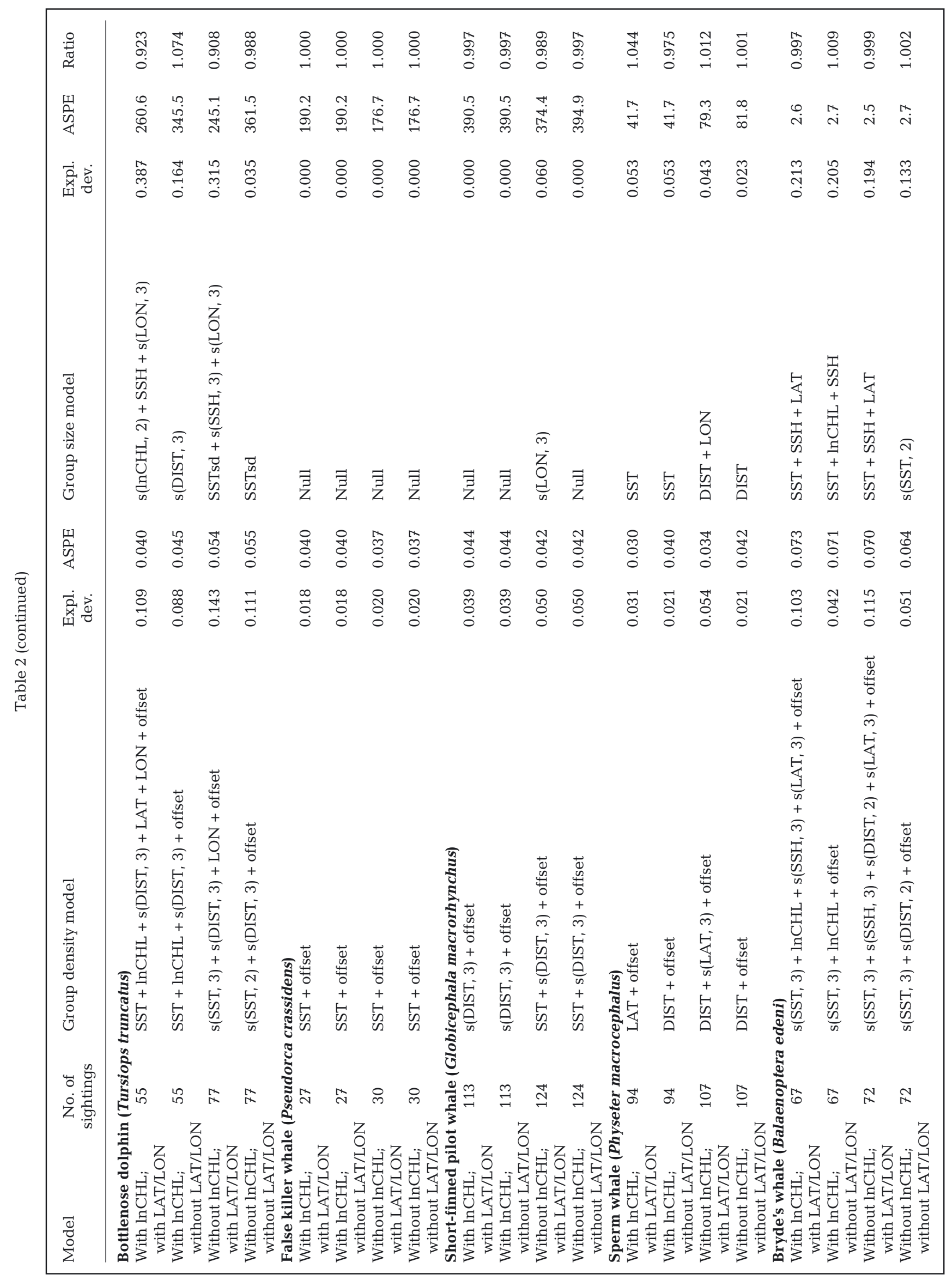




\section{RESULTS}

\section{Previous model validation}

The validation of models developed previously (Becker et al. 2012b) using novel 2010 survey data within the HI EEZ yielded mixed results (Table 3). For pantropical spotted dolphins, spinner dolphins, rough-toothed dolphins, and short-finned pilot whale, the observed-to-predicted ratios were close to 1 (range: 0.87-1.44) and similar to previous results for the 2002 survey (Becker et al. 2012b). In contrast, observed-to-predicted ratios were markedly $>1$ (range: 1.93-8.36) for striped dolphins, bottlenose dolphins, false killer whales, sperm whales, and Bryde's whales, indicating that observed densities were 2-8 times greater than the predicted densities. A visual comparison (Fig. 2) of the model-predicted density maps for 2002 (on which the models were based) and for 2010 (the novel survey year) revealed that geographic patterns of predicted density were similar in these 2 years for all species except sperm whales and bottlenose dolphins, for which the areas of greatest densities differed and the total abundance was under-predicted for 2010. For Bryde's whale, the area of greatest predicted density was the same in 2010 as in 2002, in the northwestern portion of the study area, but actual sighting locations during 2010 were concentrated farther south along the Hawaiian Islands chain than during 2002 (Fig. 2). This suggests that the predictors included in the original Becker et al. (2012b) models for sperm whales, bottlenose dolphins, and Bryde's whales did not adequately capture habitat-based density patterns across years.

\section{New models}

The additional survey data for 2010-2012 allowed us to update the habitat-based density models with a greater sample size (number of sightings and survey effort), potentially allowing different predictors to be selected (Table 2). The most commonly selected predictor variables for the group density models were SST and distance to land, while $\operatorname{lnCHL}$ and SSH were selected less frequently. In most cases, when LAT and LON were included as potential predictors, the final models included one or both of these terms. Within each species, the remaining selected variables were

Table 3. Predicted (Pred.) and 'observed' (Obs.) abundance (density) estimates (i.e. including segment-specific predicted versus observed numbers of animals encountered [animals $\mathrm{km}^{-2}$ ] within a standard line-transect calculation of abundance) for the original Becker et al. (2012b) models developed using the 1997-2006 data, as validated on 2010 survey data. For comparison, 2002 estimates are also shown. Obs./Pred. indicates the ratio of the estimates, which is ideally close to 1. Also shown is the average squared prediction error (ASPE) for the encounter rate (ER) and group size (GS) models; lower values indicate better predictive performance. For scientific species names see Table 2

\begin{tabular}{|c|c|c|c|c|c|c|}
\hline \multirow[t]{2}{*}{ Species } & \multirow[t]{2}{*}{ Year } & \multirow[t]{2}{*}{ Obs./Pred. } & \multirow{2}{*}{$\begin{array}{l}\text { Obs. abundance } \\
\text { (density) }\end{array}$} & \multirow{2}{*}{$\begin{array}{l}\text { Pred. abundance } \\
\text { (density) }\end{array}$} & \multicolumn{2}{|c|}{ ASPE } \\
\hline & & & & & ER & GS \\
\hline \multirow[t]{2}{*}{ Pantropical spotted dolphin } & 2002 & 0.644 & $8145(0.003)$ & $12644(0.005)$ & 0.028 & 494 \\
\hline & 2010 & 0.870 & $10757(0.004)$ & $12368(0.005)$ & 0.031 & 1825 \\
\hline \multirow[t]{2}{*}{ Spinner dolphin } & 2002 & 0.916 & $3078(0.001)$ & $3359(0.001)$ & 0.015 & 1553 \\
\hline & 2010 & 1.130 & $3080(0.001)$ & $2727(0.001)$ & 0.008 & 2307 \\
\hline \multirow[t]{2}{*}{ Striped dolphin } & 2002 & 1.166 & $9036(0.004)$ & $7751(0.003)$ & 0.030 & 1538 \\
\hline & 2010 & 1.934 & $17477(0.007)$ & $9038(0.004)$ & 0.042 & 1255 \\
\hline \multirow[t]{2}{*}{ Rough-toothed dolphin } & 2002 & 1.548 & $12181(0.005)$ & $7867(0.003)$ & 0.051 & 140 \\
\hline & 2010 & 1.436 & $13184(0.005)$ & $9181(0.004)$ & 0.052 & 543 \\
\hline \multirow[t]{2}{*}{ Bottlenose dolphin } & 2002 & 1.093 & $5897(0.002)$ & $5396(0.002)$ & 0.046 & 184 \\
\hline & 2010 & 8.358 & $9370(0.004)$ & $1121(0.0005)$ & 0.056 & 603 \\
\hline \multirow[t]{2}{*}{ False killer whale } & 2002 & 0.419 & $594(0.0002)$ & $1418(0.0006)$ & 0.008 & 3.39 \\
\hline & 2010 & 1.696 & $2501(0.001)$ & $1474(0.0006)$ & 0.057 & 60.8 \\
\hline \multirow[t]{2}{*}{ Short-finned pilot whale } & 2002 & 0.996 & $16515(0.007)$ & $16576(0.007)$ & 0.038 & 218 \\
\hline & 2010 & 0.994 & $17920(0.007)$ & $18025(0.007)$ & 0.048 & 908 \\
\hline \multirow[t]{2}{*}{ Sperm whale } & 2002 & 1.672 & $4358(0.002)$ & $2606(0.001)$ & 0.045 & 54.0 \\
\hline & 2010 & 3.195 & $3828(0.002)$ & $1198(0.0005)$ & 0.037 & 31.8 \\
\hline \multirow[t]{2}{*}{ Bryde's whale } & 2002 & 0.871 & $237(0.0001)$ & $272(0.0001)$ & 0.040 & 0.336 \\
\hline & 2010 & 2.239 & $717(0.0003)$ & $320(0.0001)$ & 0.111 & 0.265 \\
\hline
\end{tabular}




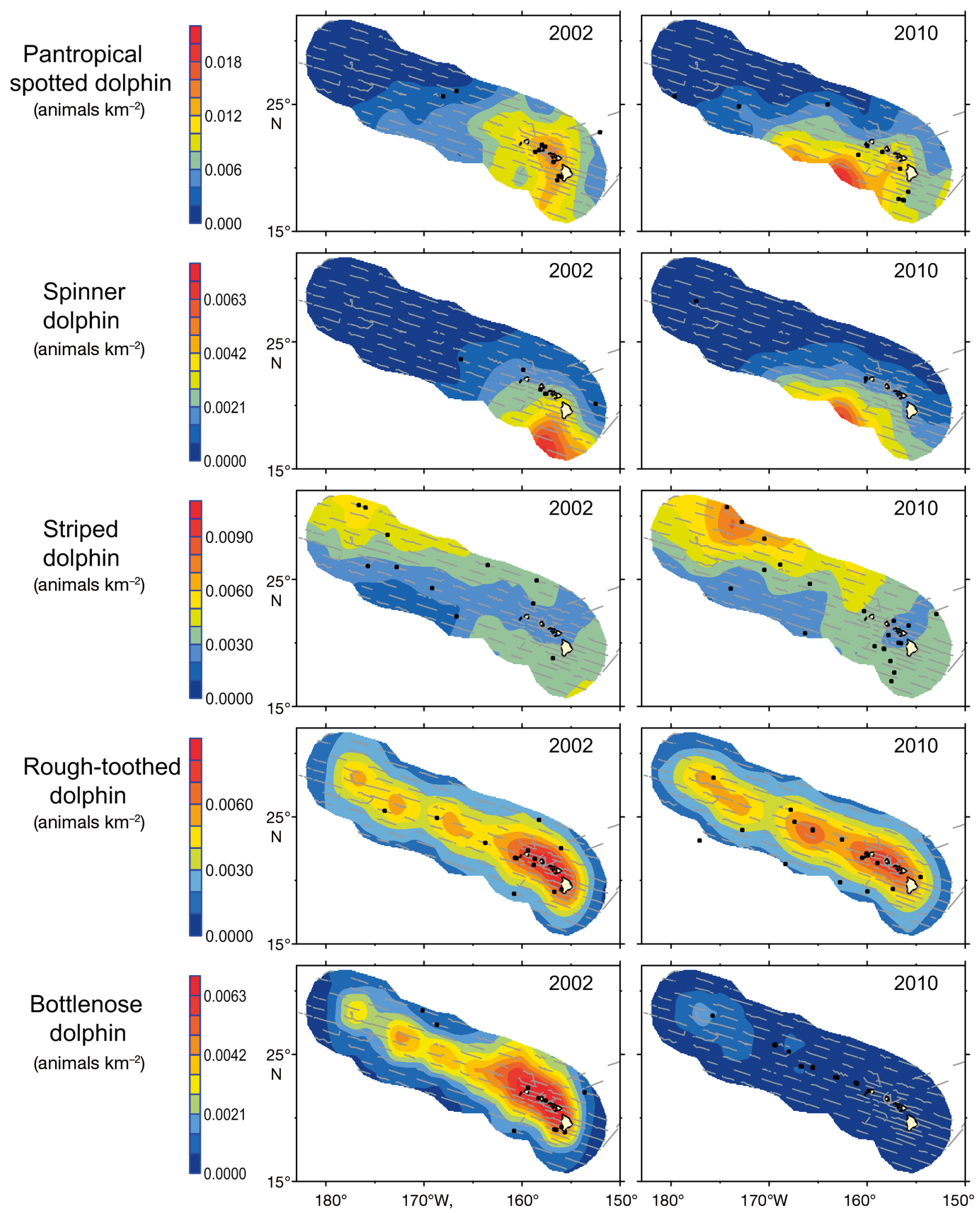

Fig. 2. Model validation results: density contours (animals $\mathrm{km}^{-2}$ ) for pantropical spotted dolphin, spinner dolphin, striped dolphin, rough-toothed dolphin, bottlenose dolphin, false killer whale, short-finned pilot whale, sperm whale, and Bryde's whale, derived from the original Becker et al. (2012b) models, predicted back on the 2002 survey transects (on which the model was based) and for a novel survey year, 2010. Survey transects are shown in gray, and black dots show locations of sightings in each year. For scientific species names see Table 2 


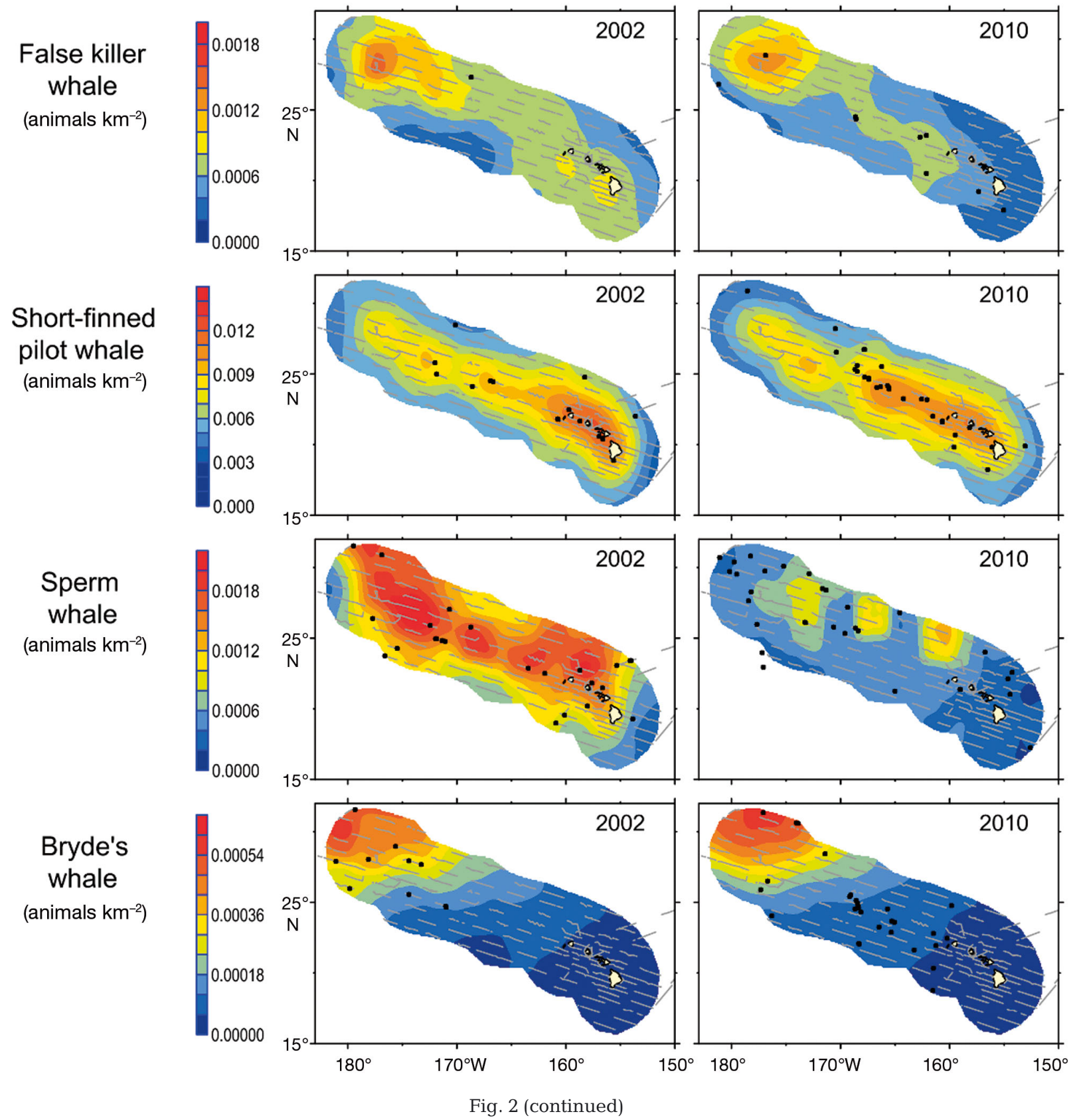

generally similar among the 4 models (Table 2), generally differing by only one variable or by the degrees of freedom selected for the smoothing spline. Predictor variables for the group size models were variable, often including SST, distance to land, SSTsd, or SSH. Three of 4 group size models for short-finned pilot whales included no predictor variables (null model, indicating no spatial variation in group size), and a null model was also applied for false killer whales because of the small number of sightings $(\mathrm{n}=30)$.
Significant positive spatial autocorrelation was observed for nearly all species at the range of evaluated distances $(0-100 \mathrm{~km})$. Moran's $I$ values across all spatial lags were $<0.10$ for all species, except bottlenose dolphins and short-finned pilot whales, for which the shortest lags $(10-20 \mathrm{~km})$ had Moran's $I$ values of up to $0.26-0.76$. False killer whales had a statistically significant negative Moran's $I$ value of -0.005 at a $40 \mathrm{~km} \mathrm{lag}$, indicating a slight tendency to be more dispersed than random. 


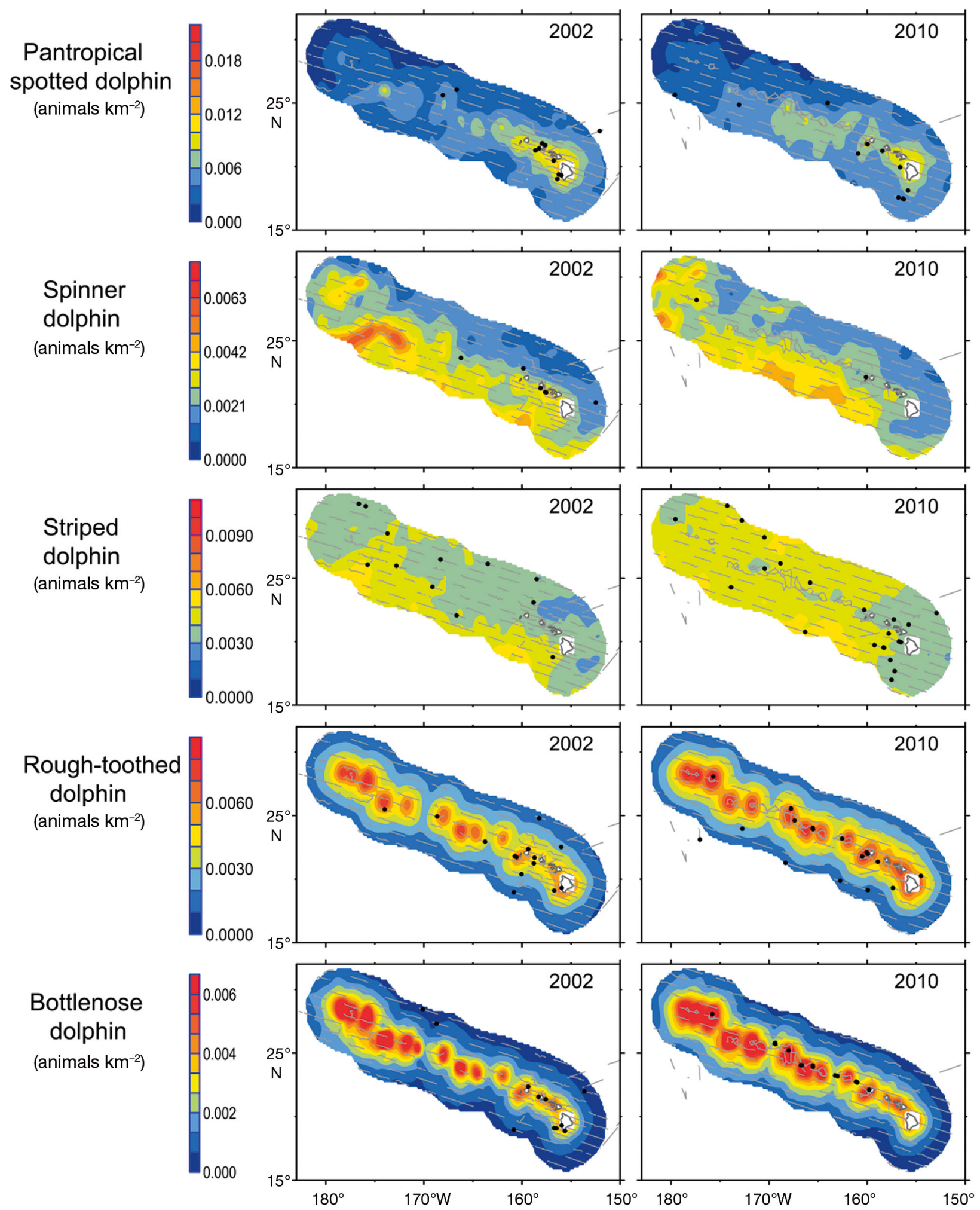

Fig. 3. Updated model-based densities (animals $\mathrm{km}^{-2}$ ) for pantropical spotted dolphin, spinner dolphin, striped dolphin, rough-toothed dolphin, bottlenose dolphin, false killer whale, short-finned pilot whale, sperm whale, and Bryde's whale, for the periods of the 2002 and 2010 surveys within the US Exclusive Economic Zone of the Hawaiian Islands. Survey transects are shown in light gray, and black dots show locations of sightings in each year. For scientific species names see Table 2 


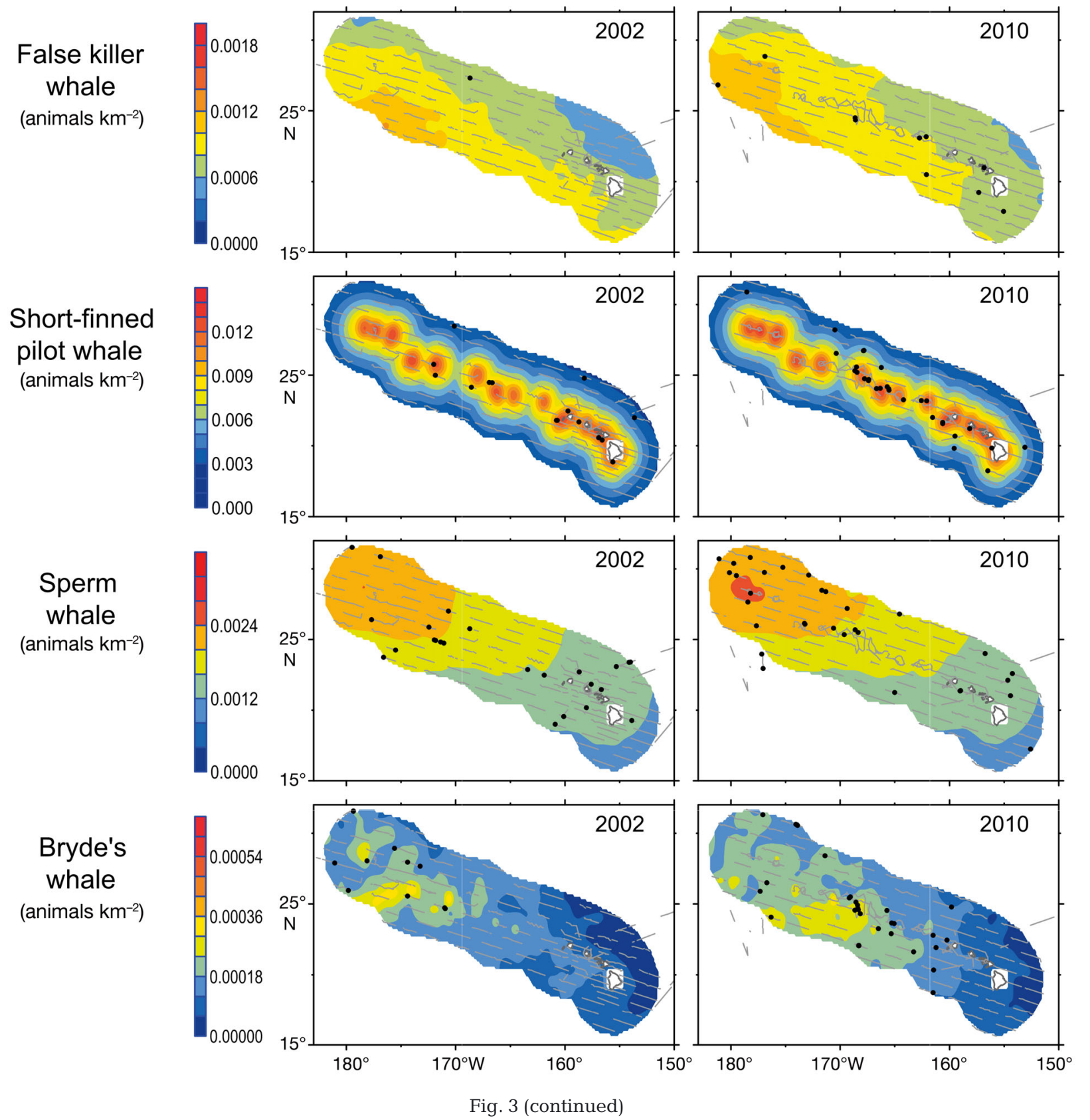

The new HI EEZ density maps for bottlenose dolphins and Bryde's whales - for which the Becker et al. (2012b) model validation results were poormatched the actual sighting locations better (Figs. 2 vs. 3). In particular, the new Bryde's whale model captured the observed southward shift in areas of concentration between 2002 and 2010 (Fig. 3). Density maps for pantropical spotted dolphin, roughtoothed dolphin, and short-finned pilot whale were similar to those in previous models (Figs. $2 \& 3$ ), although the new models showed a closer association to the Hawaiian Islands. Predicted striped dol- phin densities were spatially more uniform throughout the HI EEZ, consistent with the widespread distribution of this species in oligotrophic, deep waters of the central North Pacific. Spinner dolphins were predicted to be more broadly distributed, primarily south of the Hawaiian Archipelago, although few sightings were available for comparison. Modeled false killer densities differed between the old and new models, with the previous region of high density within the western part of the HI EEZ (Fig. 2), becoming more diffuse and shifting farther south (Fig. 3). 


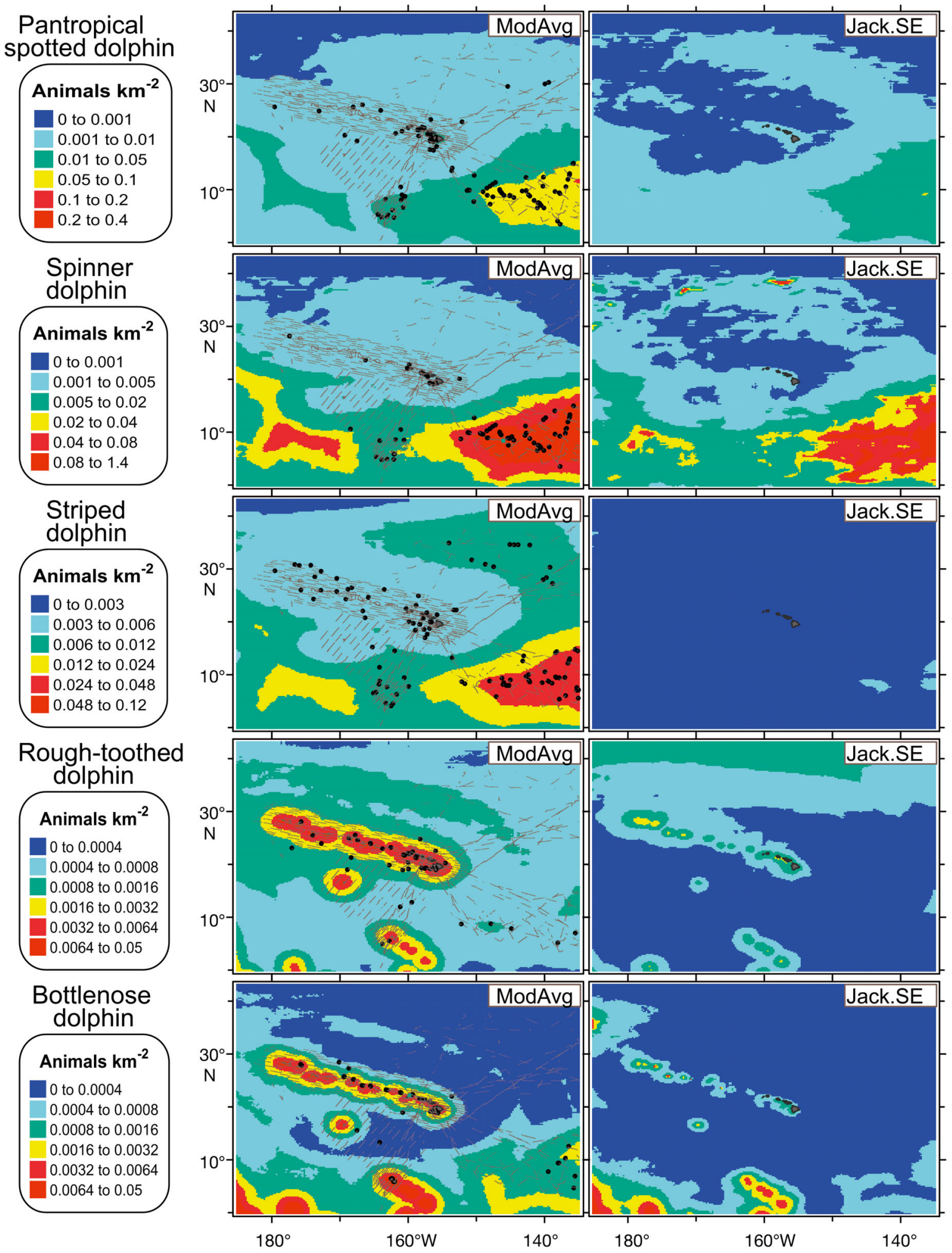

Fig. 4. New model-based densities ('ModAvg'; animals km²) and associated jackknife standard errors ('Jack.SE') for models developed using model-averaging and grid-based predictions within the central North Pacific study area for pantropical spotted dolphin, spinner dolphin, striped dolphin, rough-toothed dolphin, bottlenose dolphin, false killer whale, short-finned pilot whale, sperm whale, and Bryde's whale. In ModAvg panels survey transects are shown in light gray, and black dots are sighting locations for each species. For scientific species names see Table 2 

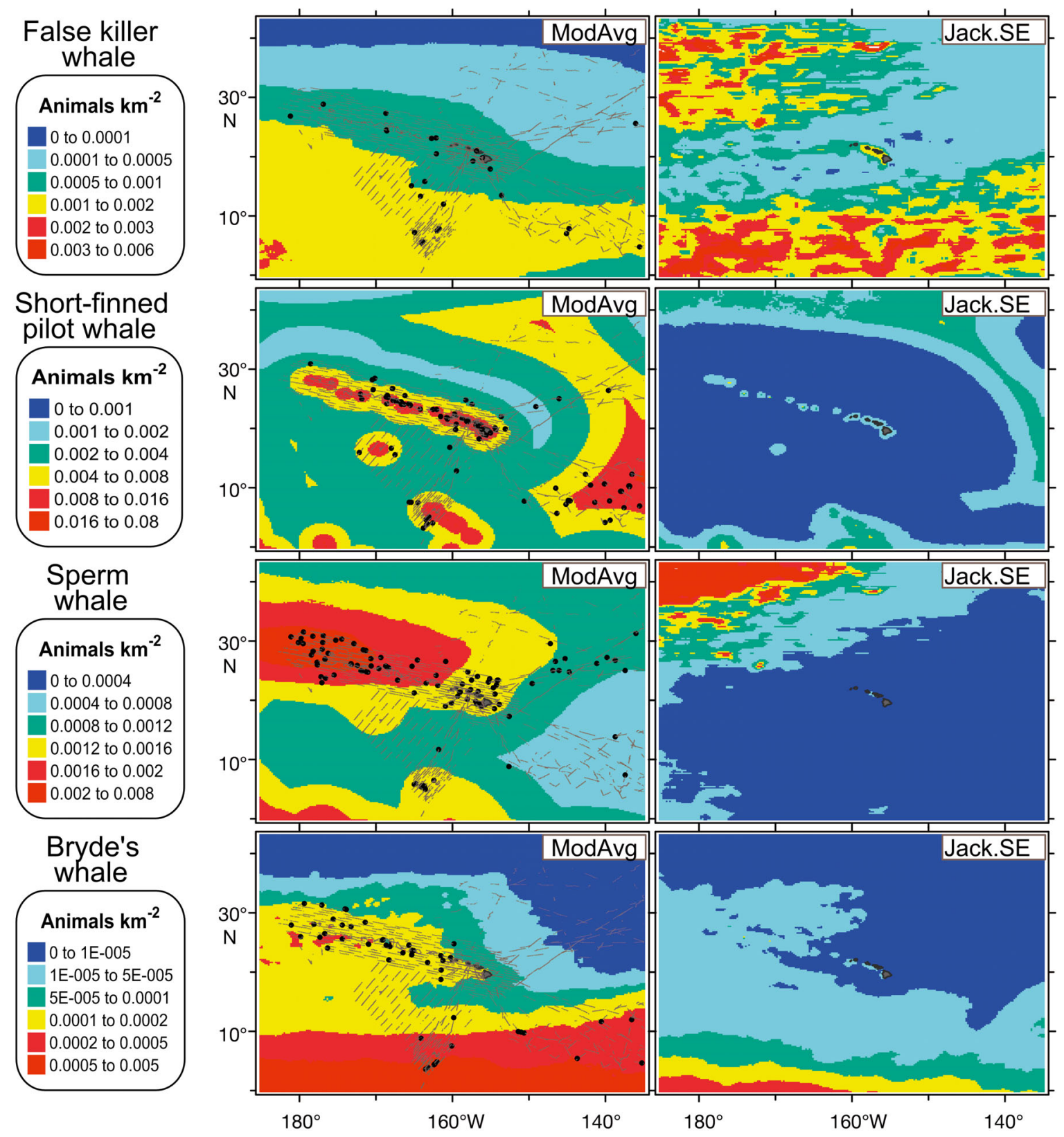

Fig. 4 (continued)

Density predictions for the larger central Pacific study area (Fig. 4) were generally successful at capturing broad-scale patterns within this region. The new grid-prediction methods yielded finer scale patterns in density compared to the previous interpolation/smoothing technique, particularly for island-associated species (e.g. bottlenose dolphins, rough-toothed dolphins, and short-finned pilot whales). Most significantly, the new methodology avoided the previous interpolation artifacts noted in Becker et al. (2012b) in areas of sparse coverage.
However, model validation in such areas remains a challenge.

Abundance estimates derived from the new models were similar to previous standard line-transect estimates within the HI EEZ (Barlow 2006, Barlow \& Rankin 2007, Bradford et al. 2013), falling within the $95 \%$ confidence limits of those estimates for all species except Bryde's whales during 2010 (Fig. 5). Thus, the overall HI EEZ abundance estimates are similar, but the habitat-based models provide additional spatial detail in density patterns that can be 
useful for management and conservation (but see the caveats in the 'Discussion' section below).

\section{DISCUSSION}

'All models are wrong but some are useful' (Box 1979)

The extent to which habitat-based models of cetacean density are useful for the management and conservation of pelagic areas depends on their accuracy. Unvalidated models that over- or underestimate regional densities or do not match known patterns of species distribution can be more damaging than helpful when trying to mitigate harm or minimize anthropogenic impacts. However, the complete absence of spatial information on species distribution and density also hampers conservation and management efforts, because it is not possible to focus on the areas of greatest importance to each species. For many marine planning activities, it is essential to understand fine-scale patterns in the distribution and abundance of individual cetacean species so impacts

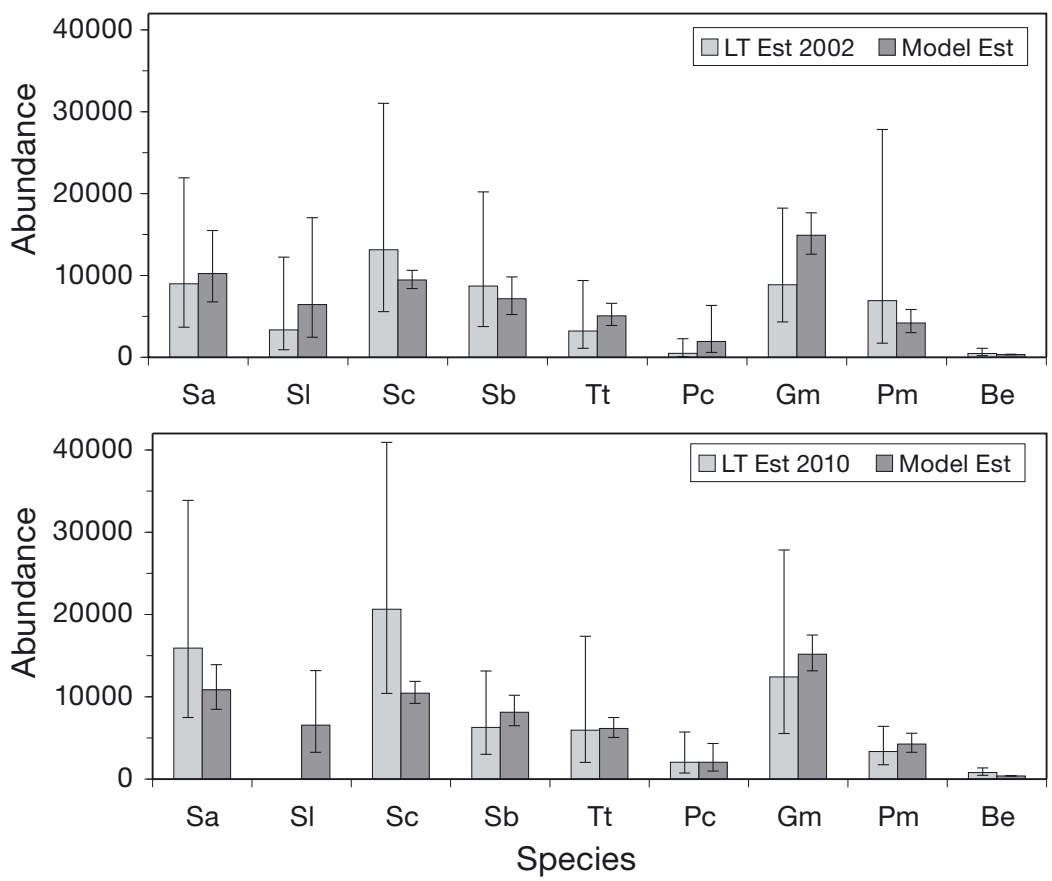

Fig. 5. Comparison of model-based abundance estimates ('Model Est') to published line-transect abundance estimates ('LT Est') for the 2002 and 2010 surveys (Barlow 2006, Barlow \& Rankin 2007, Bradford et al. 2013), with $95 \%$ log-normal confidence intervals. Model-based confidence intervals are underestimated because they do not include uncertainty in the probability of detecting animals. Species codes-Sa: pantropical spotted dolphin; Sl: spinner dolphin; Sc: striped dolphin; Sb: rough-toothed dolphin; Tt: common bottlenose dolphin; Pc: false killer whale; Gm: short-finned pilot whale; Pm: sperm whale; Be: Bryde's whale. For scientific species names see Table 2 can be properly assessed and minimized. These issues are particularly challenging for large marine areas, where species distribution and density data are limited.

The habitat-based density models developed by Becker et al. (2012b) represented a first attempt to provide spatial cetacean density and distribution data within the sparsely surveyed region of the central North Pacific; however, there were no independent data available for model validation. In the present study, we have evaluated those original models using an independent 2010 survey and subsequently developed updated models that incorporated the new 2010-2012 survey data, in hopes of improving model accuracy. We also implemented model-averaging and estimated model uncertainty using a jackknife procedure. Model predictions within the best-studied portion of our central Pacific study area, the HI EEZ, matched standard line-transect predictions well and captured geographic sighting patterns observed during the 2002 and 2010 cruises. Based on these results, the habitat-based models of cetacean density developed in this study represent an improvement over the previously available uniform density estimates and the original models developed by Becker et al. (2012b). However, there are important caveats and challenges to the use of such models for pelagic conservation and management, particularly since we were not able to validate the new models on independent data.

Some species that are known to occur within our study area were not included in the present study, because sample sizes were too limited for modeling. Pygmy and dwarf sperm whales (Kogia sima and K. breviceps), and a variety of beaked whales, including Cuvier's beaked whale Ziphius cavirostris, Blainville's beaked whale Mesoplodon densirostris, Longman's beaked whale Indopacetus pacificus and Deraniyagala's beaked whale Mesoplodon hotaula, a newly described species near Palmyra Atoll, are commonly found within the central Pacific study area (Barlow 2006, McSweeney et al. 2007, Baird et al. 2011, Rankin et al. 2011, BaumannPickering et al. 2014) but are difficult to observe at sea because of their cryptic surfacing behavior and long 
dive periods. Larger sample sizes and methods that can correct for animals missed in rough seas are necessary before robust habitat-based models can be developed.

In the current study, we have incorporated new methods to predict densities onto a systematic grid of individual $25 \times 25 \mathrm{~km}$ cells throughout the study area, rather than on individual transect segments. This represents an important first step towards minimizing smoothing artifacts, but it also highlights the need to consider the appropriate spatial and temporal scales relevant for each study area (Wiens 1989, Jaquet \& Whitehead 1996, Redfern et al. 2008, Becker et al. 2010). The $25 \mathrm{~km}$ scale models we selected here for the central Pacific study area (Fig. 4) are intended to capture broad-scale patterns within this region, while also allowing smaller scale gradients near the Hawaiian Islands to be resolved. For several of the species known to have strong island association, such as spinner dolphin, bottlenose dolphin, rough-toothed dolphin, and short-finned pilot whales, our modelbased densities match previously documented patterns (Barlow 2006, Baird et al. 2008b).

The new, grid-based prediction methods also allowed us to create monthly estimates of cetacean density throughout the study area, based on the monthly composite values of the satellite-derived environmental data. These monthly predictions from the 4 averaged models provided mean estimates for the predicted cetacean densities during the study period. Variance estimation for habitat-based density models remains challenging, because it is often unrealistic to account for all sources of uncertainty, and dependence among the various sources of uncertainty can confound variance estimation (Barlow et al. 2009). The jackknife method we used to estimate variance provided an estimate of model selection uncertainty, which is often much greater than the uncertainty in model parameters (Wintle et al. 2003). Additional uncertainty derives from other processes, such as sampling error, variation in detectability of animals with changing observation conditions, and error in the estimation of habitat variables. Measures of uncertainty for $g(0)$ and the segment-specific ESW estimates (Barlow et al. 2011, Barlow in press) could not feasibly be included in our simulations, and, therefore, the standard errors of our model-based density estimates are underestimated. Spatial autocorrelation further complicates estimation of variance in predicted densities derived from habitat-based models. In the present study, we identified positive spatial autocorrelation at varying distances from 10 to $100 \mathrm{~km}$ for 8 of the 9 species considered. Spatial autocorrelation does not nec- essarily bias mean responses or predictions of new observations (Neter et al. 1996, Diniz-Filho et al. 2003), but it can restrict the transferability of habitat models in space and time (Dormann 2007). It is therefore important that our models are not used to make predictions outside the study area and to acknowledge that our estimates of variance underestimate the true uncertainty in our model predictions. Future efforts should continue to address the dominant sources of uncertainty and to incorporate spatial autocorrelation explicitly (e.g. Booth et al. 2013).

Several of the remotely sensed oceanographic data sources have changed over the years as satellite sensors have failed and been replaced (e.g. SeaWiFS vs. MODIS) and as processing algorithms have changed (e.g. Reynolds \& Smith 1994). The effect of these changes on model accuracy cannot adequately be evaluated with the data available to us at the present time. We have attempted to minimize potential effects of the change from SeaWiFS to MODIS by using primarily MODIS chlorophyll data and calibrating the SeaWiFS chlorophyll data by regression. Sensor and input data changes will continue to affect species-habitat models in the future.

There is also a potential for bias in our density predictions. One important source of potential bias derives from our assumption that the probability of detecting animals on the transect line, $g(0)$, is equal to previous estimates derived from a subset of our survey data collected under the same range of observation conditions (Barlow 2003, 2006). However, the proportion of effort in various sea states may differ across surveys and study areas, and ideally sea-statespecific estimates of $g(0)$ should be applied to each transect segment, as with the estimated ESW values in this study. Barlow (in press) has developed seastate-specific estimates of $g(0)$, and the incorporation of segment-specific $g(0)$ values would more accurately account for variation in detection probabilities and improve our habitat-based density models in the future.

Another source of potential bias is apparent when comparing our results to similar modeling studies in adjacent regions of the North Pacific, including the CCE and ETP (Ferguson et al. 2006, Redfern et al. 2008, Barlow et al. 2009, Becker et al. 2012c, Forney et al. 2012). At the boundaries between these different study areas, density estimates for species found in both regions should ideally converge. However, density estimates from models developed for the different study areas can be quite different. For example, estimated densities of striped dolphins along the northeastern boundary of the present study 
area (about $135^{\circ} \mathrm{W}$ longitude) range from about 0.003 to 0.012 animals km $\mathrm{km}^{-2}$ (Fig. 4). This is lower than habitat-based density estimates along the nearby western boundaries of the CCE (0.02-0.14 animals $\left.\mathrm{km}^{-2}\right)$ (Becker et al. 2012c). Such edge effects create challenges for end-users and pelagic conservation when model results from different study areas are combined. A potential solution to this problem is to develop broader scale models spanning multiple ecoregions, but for the CCE and ETP this has been shown to reduce model accuracy, possibly because of differences in species-environment relationships across eco-regions (Barlow et al. 2009). Alternately, suitable interpolation and averaging methods may be applied at the edges of adjacent study areas to ensure continuity of density estimates across ecoregions. The data sets used in this study and those presented by Forney et al. (2012) may offer an ideal opportunity to investigate such approaches in the future.

One final source of uncertainty in our models that cannot currently be addressed is introduced by cetacean behavior that does not fit into the framework of line-transect sampling. In particular, species such as false killer whales that have complex, widely dispersed subgroups that are behaviorally associated but span many 10s of kilometers (Baird et al. 2008a, Bradford et al. 2014) create analytical challenges when estimating density using standard or habitatbased line-transect analyses. In the present analysis, we have attempted to minimize the effect of this by limiting our models to include only the subgroups that fell within the effective strip width estimated from other detected subgroups. As additional surveys are conducted and larger sample sizes of such widely dispersed groups become available, it may be possible to evaluate alternate approaches for such species.

Keeping the above caveats in mind, it is our hope that the models presented in this study can provide the basis for examining the broad-scale patterns of pelagic species distribution and for considering impacts more broadly and comprehensively. These models will be made freely available for managers and marine resource users in the form of geographic information system species-density layers, to be served through the NOAA Cetacean and Sound Mapping Web site (http://cetsound.noaa.gov/index. html).

Acknowledgements. This study would not have been possible without the dedication of the marine mammal observers, cruise leaders, and vessel crew who worked hard on surveys conducted over the $15 \mathrm{yr}$ period collecting the data that we used here. Chief Scientists for the survey cruises included Tim Gerrodette, Lisa Ballance, and 2 of the co-authors (J.B. and E.M.O.). We thank Chip Johnson, Julie Rivers (US Pacific Fleet, US Navy) and Sean Hanser (Naval Facilities Engineering Command, Pacific, US Navy), for providing us with the opportunity and funding to conduct this analysis. We also thank Jim Carretta and Scott Benson and 3 anonymous reviewers for their helpful reviews of an earlier draft of this manuscript. Additional funding for this study was provided by NOAA's Southwest Fisheries Science Center and Pacific Islands Fisheries Science Center. Surveys were conducted in accordance with institutional, national and international guidelines concerning the use of animals in research and/or the sampling of endangered species, and under the following permits: National Marine Fisheries Service, Nos. 774-1437, 14097, and 15240; State of Hawaii, No. SH2002-11, and Papahānaumokuākea Marine National Monument, No. PMNM2010-053

\section{LITERATURE CITED}

Akaike H (1973) Information theory and an extension of the maximum likelihood principle. In: Petran BN, Csàaki $F$ (eds) Proceedings of the 2nd international symposium on information theory. Akadèemiai Kiadi, Budapest, p 267-281

Baird RW, Gorgone AM, McSweeney DJ, Webster DL and others (2008a) False killer whales (Pseudorca crassidens) around the main Hawaiian Islands: long-term site fidelity, inter-island movements, and association patterns. Mar Mamm Sci 24:591-612

Baird RW, Webster DL, Mahaffy SD, McSweeney DJ, Schorr GS, Ligon AD (2008b) Site fidelity and association patterns in a deep-water dolphin: Rough-toothed dolphins (Steno bredanensis) in the Hawaiian Archipelago. Mar Mamm Sci 24:535-553

Baird RW, Schorr GS, Webster DL, Mahaffy SD, McSweeney DJ, Hanson MB, Andrews RD (2011) Openocean movements of a satellite-tagged Blainville's beaked whale (Mesoplodon densirostris): evidence for an offshore population in Hawai'i? Aquat Mamm 37: 506-511

Barlow J (2003) Preliminary estimates of the abundance of cetaceans along the U.S. west coast: 1991-2001. Administrative report LJ-03-03, NOAA NMFS Southwest Fisheries Science Center, La Jolla, CA

$>$ Barlow J (2006) Cetacean abundance in Hawaiian waters estimated from a summer/fall survey in 2002. Mar Mamm Sci 22:446-464

Barlow J (in press) Inferring trackline detection probabilities $(g(0))$ for cetaceans from apparent densities in different survey conditions. Mar Mamm Sci

Barlow J, Rankin S (2007) False killer whale abundance and density: preliminary estimates for the PICEAS study areas south of Hawaii and new estimates for the US EEZ around Hawaii. Administrative Report LJ-0702, NOAA NMFS Southwest Fisheries Science Center, La Jolla, CA

Barlow J, Ferguson MC, Becker EA, Redfern JV and others (2009) Predictive modeling of cetacean densities in the eastern Pacific Ocean. NOAA Tech Memo NMFSSWFSC-444 
Barlow J, Ballance LT, Forney KA (2011) Effective strip widths for ship-based line-transect surveys of cetaceans. NOAA Tech Memo NMFS-SWFSC-484

Baumann-Pickering S, Roch MA, Brownell RL Jr, Simonis AE and others (2014) Spatio-temporal patterns of beaked whale echolocation signals in the North Pacific. PLoS ONE 9:e860722

> Beale CM, Lennon JJ, Yearsley JM, Brewer MJ, Elston DA (2010) Regression analysis of spatial data. Ecol Lett 13: 246-264

> Becker EA, Forney KA, Ferguson MC, Foley DG, Smith RC, Barlow J, Redfern JV (2010) Comparing California Current cetacean-habitat models developed using in situ and remotely sensed sea surface temperature data. Mar Ecol Prog Ser 413:163-183

> Becker EA, Foley DG, Forney KA, Barlow J, Redfern JV, Gentemann CL (2012a) Forecasting cetacean abundance patterns to enhance management decisions. Endang Species Res 16:97-112

Becker EA, Forney KA, Foley DG, Barlow J (2012b) Density and spatial distribution patterns of cetaceans in the central North Pacific based on habitat models. NOAA Tech Memo NMFS-SWFSC-490

Becker EA, Forney KA, Ferguson MC, Barlow J, Redfern JV (2012c) Predictive modeling of cetacean densities in the California Current ecosystem based on summer/fall ship surveys in 1991-2008. NOAA Tech Memo NMFSSWFSC-499

Booth CG, Embling C, Gordon J, Calderan SV, Hammond PS (2013) Habitat preferences and distribution of the harbour porpoise Phocoena phocoena west of Scotland. Mar Ecol Prog Ser 478:273-285

Box GEP (1979) Robustness in the strategy of scientific model building. In: Launer RL, Wilkinson GN (eds) Robustness in statistics. Academic Press, New York, NY, p 201-236

Bradford AL, Forney KA, Oleson EM, Barlow J (2013) Linetransect abundance estimates of cetaceans in the Hawaiian EEZ. Document PSRG-2013-18 presented to the Pacific Scientific Review Group, April 2-4, 2013, La Jolla CA. Available from NOAA NMFS Pacific Islands Fisheries Science Center, Honolulu, HI

Bradford AL, Forney KA, Oleson EM, Barlow J (2014) Accounting for subgroup structure in line-transect abundance estimates of false killer whales (Pseudorca crassidens) in Hawaiian waters. PLoS ONE 9:e90464

Buckland ST, Anderson DR, Burnham KP, Laake JL, Borchers DL, Thomas L (2001) Introduction to distance sampling: estimating abundance of biological populations. Oxford University Press, New York, NY

Burnham KP, Anderson DR (1998) Model selection and inference. A practical information theoretic approach. Springer-Verlag, New York, NY

Claeskens G, Hjort NL (2008) Model selection and model averaging. Cambridge University Press, New York, NY

> Diniz-Filho JAF, Bini LM, Hawkins BA (2003) Spatial autocorrelation and red herrings in geographical ecology. Glob Ecol Biogeogr 12:53-64

> Dormann CF (2007) Effects of incorporating spatial autocorrelation into the analysis of species distribution data. Glob Ecol Biogeogr 16:129-138

Efron B, Tibshirani RJ (1993) An introduction to the bootstrap. Chapman and Hall, New York, NY
Ferguson MC, Barlow J, Fiedler P, Reilly SB, Gerrodette T (2006) Spatial models of delphinid (family Delphinidae) encounter rate and group size in the eastern tropical Pacific Ocean. Ecol Modell 193:645-662

Forney KA (2000) Environmental models of cetacean abundance: reducing uncertainty in population trends. Conserv Biol 14:1271-1286

Forney KA, Ferguson MC, Becker EA, Fiedler PC and others (2012) Habitat-based spatial models of cetacean density in the eastern Pacific Ocean. Endang Species Res 16: 113-133

Goetz KT, Montgomery RA, Ver Hoef JM, Hobbs RC, Johnson DS (2012) Identifying essential summer habitat of the endangered beluga whale Delphinapterus leucas in Cook Inlet, Alaska. Endang Species Res 16:135-147

Hamilton TA, Redfern JV, Barlow J, Ballance LT and others (2009) Atlas of cetacean sightings from Southwest Fisheries Science Center cetacean ecosystem surveys: 1986-2005. NOAA Tech Memo NMFS-SWFSC-440

Hastie TJ, Tibshirani RJ (1990) Generalized additive models, Vol 43. Chapman \& Hall/CRC, Boca Raton, FL

> Jaquet N, Whitehead H (1996) Scale-dependent correlation of sperm whale distribution with environmental features and productivity in the South Pacific. Mar Ecol Prog Ser 135:1-9

Keller CA, Garrison L, Baumstark R, Ward-Geiger LI, Hines E (2012) Application of a habitat model to define calving habitat of the North Atlantic right whale in the southeastern United States. Endang Species Res 18: 73-87

Kinzey D, Olson P, Gerrodette T (2000) Marine mammal data collection procedures on research ship line-transect surveys by the Southwest Fisheries Science Center. Report No. LJ-00-08, Southwest Fisheries Science Center, La Jolla, CA

McSweeney DJ, Baird RW, Mahaffy SD (2007) Site fidelity, associations and movements of Cuvier's (Ziphius cavirostris) and Blainville's (Mesoplodon densirostris) beaked whales off the island of Hawai'i. Mar Mamm Sci 23: 666-687

Neter J, Kutner MH, Nachtsheim CJ, Wasserman W (1996) Applied linear statistical models. Irwin, Chicago, IL

R Core Team (2014) R: A language and environment for statistical computing. R Foundation for Statistical Computing, Vienna. www.R-project.org/

> Rankin S, Baumann-Pickering S, Yack T, Barlow J (2011) Description of sounds recorded from Longman's beaked whale, Indopacetus pacificus. J Acoust Soc Am 130: EL339-EL344, doi:10.1121/1.3646026

> Redfern JV, Barlow J, Ballance LT, Gerrodette T, Becker EA (2008) Absence of scale dependence in dolphin-habitat models for the eastern tropical Pacific Ocean. Mar Ecol Prog Ser 363:1-14

> Redfern JV, McKenna MF, Moore TJ, Calambokidis J and others (2013) Assessing the risk of ships striking large whales in marine spatial planning. Conserv Biol 27: 292-302

Reynolds RW, Smith TM (1994) Improved global sea surface temperature analyses using optimum interpolation. J Clim 7:929-948

Reynolds RW, Smith TM, Liu C, Chelton DB, Casey KS, Schlax MG (2007) Daily high-resolution-blended analyses for sea surface temperature. J Clim 20:5473-5496

Syphard AD, Franklin J (2009) Differences in spatial pre- 
dictions among species distribution modeling methods vary with species traits and environmental predictors. Ecography 32:907-918

US Department of the Navy (2008) Hawaii Range Complex, Final Environmental Impact Statement/Overseas Environmental Impact Statement (EIS/OEIS). Prepared by Pacific Missile Range Facility, Kekaha, HI

> Wessel P, Smith WHF (1998) New, improved version of the

Editorial responsibility: Patrick Halpin,

Durham, North Carolina, USA
Generic Mapping Tools, released. Eos Trans AGU 79: 579, doi:10.1029/98EO00426

> Wiens JA (1989) Spatial scaling in ecology. Funct Ecol 3: 385-397

> Wintle BA, McCarthy MA, Volinsky CT, Kavanagh RP (2003) The use of Bayesian model averaging to better represent uncertainty in ecological models. Conserv Biol $17: 1579-1590$

Submitted: September 1, 2013; Accepted: July 10, 2014

Proofs received from author(s): December 4, 2014 